\title{
Prelaryngeal Lymph Node
}

National Cancer Institute

\section{Source}

National Cancer Institute. Prelaryngeal Lymph Node. NCI Thesaurus. Code C147454.

A lymph node located anterior to the larynx. 